\title{
Daylight Performance of Colonial Houses in Surabaya
}

\author{
I Gusti N. Antaryama ${ }^{1, *}$, Sri N.N. Ekasiwi ${ }^{1}$, Irvansyah ${ }^{1}$ and Muhammad S. Ulum ${ }^{1}$ \\ ${ }^{1}$ Department of Architecture, Institut Teknologi Sepuluh Nopember, Kampus ITS Sukolilo Surabaya 60111, Indonesia
}

\begin{abstract}
The present study explores and evaluates daylight performance of colonial houses in Surabaya. It is a prelimanary study that is aimed to further extent the knowledge regarding the daylight conditions in the colonial houses which is limited and previously arised only by small number of studies. Daylight condition of the building is collected through a field measurement which is conducted in four colonial houses in Surabaya during the dry season. The daylight factor of the building is then analyzed and evaluated to indicate the daylight performance of the houses. The study found that not all of the colonial houses under study were able to suffice the minimum daylight requirements for domestic activities. Good daylight performance can be achieved by the building design and the appropriate utilisation schedule of window. Design strategies used in the colonial house reflect the adapatability of the building to the warm humid climate of Surabaya.
\end{abstract}

\section{Introduction}

Energy efficiency is one of the goal of environmentally responsive architecture. One method of attaining this goal is by introducing natural light in the building. Aside from many excellent daylight design strategies that were offered by some of the Indonesian traditional buildings [1], one example that is worth to study is daylight condition in colonial house [2]. This argument is based on the previous studies which acknowledged the good climatic response of the colonial building [3, 4, 5, 6, 7]. The studies however paid less attention on daylighting and generally concentrated on the thermal aspect of the building.

Daylight plays an important role in human life [8]. It influences our health, It enables us to carry out visual task, and it influence our social interaction. Daylight consists of two components, i.e. sunlight and skylight. The balance of these two components will determine characteristic of a given place, and therefore affects design of a building [8].

Variables influence daylighting condition and performance in building are sky conditions, obstructions on the site, building elements such as overhangs, light shelves, louvres, glazing materilas, window size/area, room geometry, interior surfaces and shading controls [9].

Researches concerning daylighting in building in warm humid tropics often focused in small size of building such as traditional [1] and modern houses, and large size of building such as offices [10]. A very small number of studies considered the colonial house. It is the intention of this study therefore to explore and evaluate daylight performance of the colonial house. In addition, the study is also aimed to further extent the knowledge regarding the daylight condition of the colonial building.

\section{Methods}

The present study employs field measurement to gather information about daylight conditions in the colonial house. The following paragraphs describe detailed methodology of the study.

\subsection{Colonial house}

Four colonial houses in Surabaya are taken as subject of the study [11]. The houses are located in four different areas, namely in Tampak Siring street, Musi street, Sutomo street and Nias street. The houses are assigned with different codes: CH1- Siring for Siring street, CH2Nusi for Nusi street, CH3-Sutomo for Sutomo street and $\mathrm{CH} 4-\mathrm{Musi}$ for Musi street. CH1-Siring faces east, $\mathrm{CH} 2-$ Nias east, CH3-Sutomo north-west, and CH4-Musi west. Illustration of the houses is given in Fig. 1 below.

Three houses have a new building extension at different sides of the original colonial building. House CH1-Siring which faces east has a separate building extension at the back of the house. New extension in house $\mathrm{CH} 3$-Sutomo is directly attached in three sides of the original building. Similar to CH1-Siring, CH4-Musi has a new extension at the backyard.

\subsection{Field measurements}

Corresponding author: antaryama001@gmail.com 


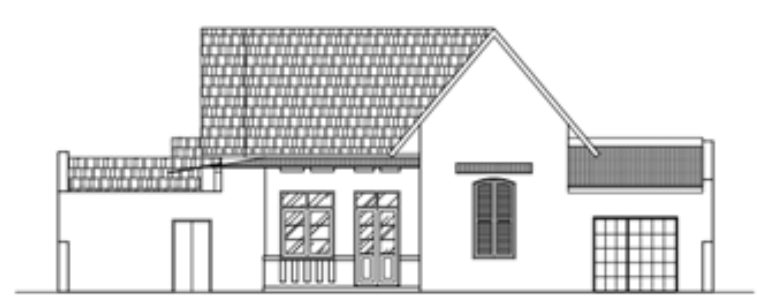

(a) CH1-Siring

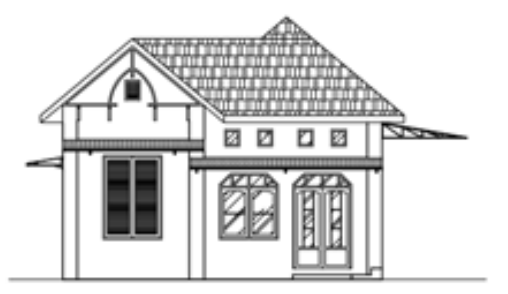

(b) $\mathrm{CH} 2-\mathrm{Nias}$

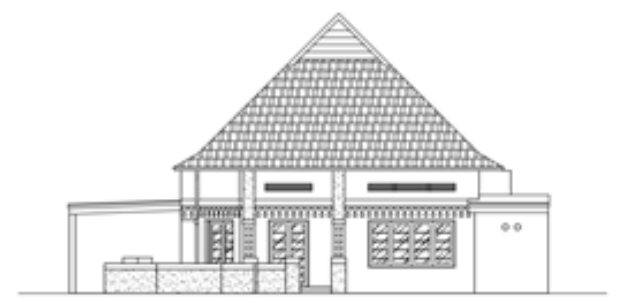

(c) $\mathrm{CH} 3-$ Sutomo

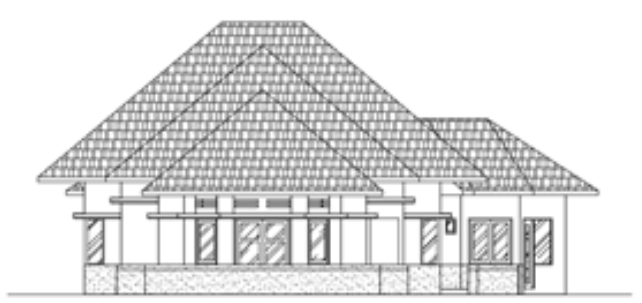

(d) CH4-Musi

Fig. 1. Elevation of the four houses under study [11]

Field measurements were conducted during the dry season in the four houses under study. Two main rooms were considered representing the dominant activities in the building. The rooms are bedroom and living room/reception room. All of the rooms are at the perimeter of the building facing open space.

The measurement of illuminance was taken indoors in the two main room previously mentioned and outdoors in the backyard of the house. Illuminance was measured using lux meter for three consecutive days. For the indoor measurement, the lux meter was set in the middle of the room at the height of $0.75 \mathrm{~m}$, and for the outdoor measurement the lux meter was positioned in an open area at the height of $0.75 \mathrm{~m}$.

\subsection{Evaluation}

Evaluation of daylight performance is made on the basis of daylight factor (DF) calculated for each houses.
Recommended values for residential building are taken from UK Building Research Establishment/BRE that is cited in [12]. The recommended DF values are $0.5 \%$ for bedroom, $1 \%$ for living room, and $2 \%$ for kitchen.

\section{Results and discussion}

Analysis is divided in to three parts. The first part analyses the general climatic condition and outdoor illuminance. The second part analyses and evaluates the daylight performance of the house. Finally environmental potentials of the building design are discussed.

\subsection{Outdoor illuminance}

Fig. 2 shows the outdoor illuminance recorded during the field measurement. It can be seen that the outdoor illuminance varies according to sky condition during the measurement. The sky is generally clear during the field study. Under this conditions, the sky dome is covered around $30 \%$ by the cloud, and the illumination levels are between 53.500 to 128.400 lux [9].

Outdoor illuminance in the Nias street is the highest (max. 80.000 lux), and decreases from max. 62.000 lux in Musi street, 61.000 lux in Siring street and 30.000 lux in Sutomo street respectively. These values will influence indoor illuminance of the building.

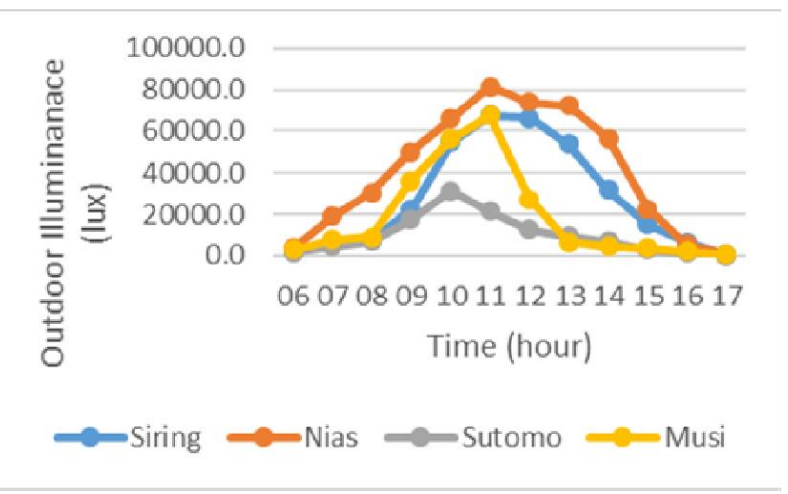

Fig. 2. Outdoor illuminance recorded during the field study

\subsection{Daylight performance}

\subsubsection{Performance of each house}

Daylight factor is used to evaluate daylight performance of the building. Daylight factor of each house is given in the following figures and tables.

Fig. 3(a) and Tables 1 and 2. show daylight performance in the house CH1-Siring. It can be seen in this figure that DF in the living room is generally less than the recommended value $(1 \%$ or more). The value ranges from around 0.3 to $19 \%$ and occur between 10 to 16.00 p.m. An exception occurs in during the morning from 06.00 to $09.00 \mathrm{a} . \mathrm{m}$. and in the late afternoon from 16.00 to 17.00 p.m. During these time the value can range from 3 to $19 \%$. Low DF values were also recorded in the bedroom. The DF were generally less than $0.5 \%$ 
for most of the time. Only in the early morning the DF can be $1.25 \%$. This indicates that daylight performance in CH1-Siring is not sufficient for conducting activities. The house therefore can be said as having under performance.

In the case of HC2-Nias, the performance is slightly better that the house in Tampak Siring street (Fig. 1(b). $\mathrm{DF}$ in the living room is generally more than the standard (1 to 19\%). As can be seen in the Table 1., the $1 \%$ standard cannot be achieved only during the day especially from 11.00 a.m. to 13.00 p.m. DF in the bedroom is generally lower than that in the living room $(0.7$ to $0.9 \%$ ) (see Table 2 .). The recommended values are attained only during the morning from 06.00 to 09.00 a.m. The daylight performance of the living room can be considered good, whereas the bedroom insufficient.

The third house, i.e. HC3-Sutomo, experienced better daylight as compared with the two previous houses (Fig. $3(\mathrm{c})$ ). DF in the living room is more than the standard DF for most of the time (Table 1.). The values ranged from 1 to $5.6 \%$. Similar tendency also occurs in the bedroom (Table 2.). Here the DF varied between 0.5 to $1 \%$. Similar tendency to that recorded in the two previous houses can also be found in HC3-Sutomo: DF in the living room are higher than that in the bedroom.

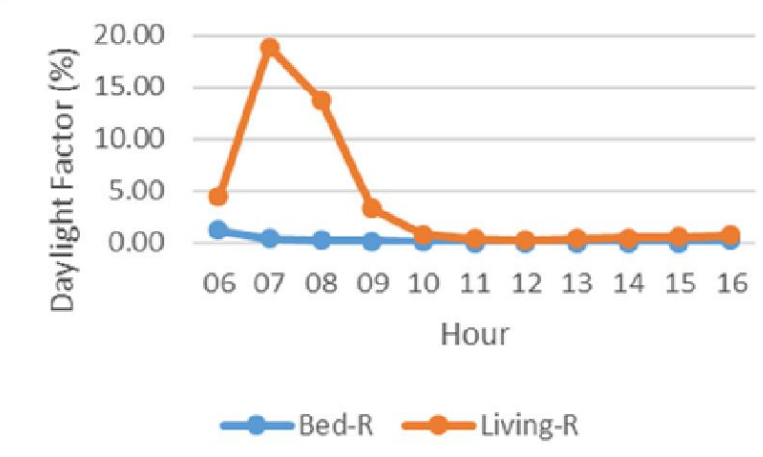

(a) CH1-Siring

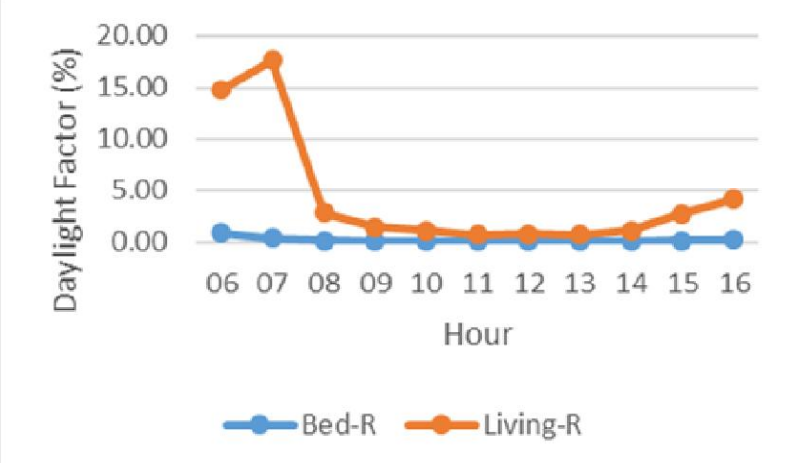

(b) $\mathrm{CH} 2-\mathrm{Nias}$

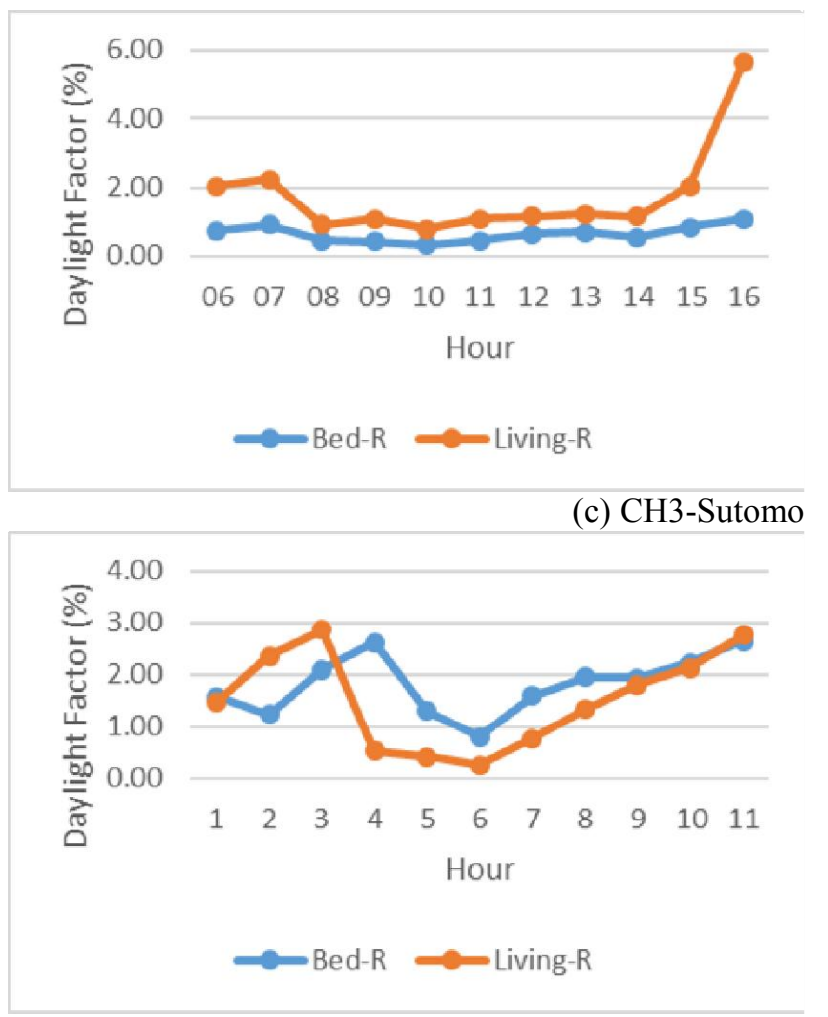

Fig. 3. Daylight factor of the four houses under study

(d) CH4-Musi

The last house, i.e. HC4-Musi, recorded slightly lower DF than that of HC3-Sutomo especially in the living room (see Fig. 3(d) and Table 1 and 2)). The minimum DF in this room is $0.27 \%$ and the maximum $2.76 \%$. Conversely, DF in the bedroom of the HC4-Musi tended to be higher that than in the HC3-Sutomo. The minimum value is $0.81 \%$ and the maximum is $2.66 \%$.

Table 1. Daylight factor in the living room

\begin{tabular}{|c|c|c|c|c|}
\hline \multirow{2}{*}{ Time } & \multicolumn{4}{|c|}{ DF in Colonial House (\%) } \\
\cline { 2 - 5 } & Siring & Nias & Sutomo & Musi \\
\hline 06 & 4.47 & 14.89 & 2.03 & 1.49 \\
\hline 07 & 18.92 & 17.68 & 2.22 & 2.35 \\
\hline 08 & 13.72 & 2.83 & 0.90 & 1.91 \\
\hline 09 & 3.30 & 1.46 & 1.07 & 0.54 \\
\hline 10 & 0.82 & 1.11 & 0.77 & 0.42 \\
\hline 11 & 0.40 & 0.77 & 1.08 & 0.26 \\
\hline 12 & 0.28 & 0.83 & 1.14 & 0.77 \\
\hline 13 & 0.37 & 0.76 & 1.21 & 1.34 \\
\hline 14 & 0.51 & 1.18 & 1.15 & 1.80 \\
\hline 15 & 0.61 & 2.76 & 2.03 & 2.13 \\
\hline 16 & 0.77 & 4.14 & 5.65 & 2.76 \\
\hline
\end{tabular}

In the HC4-Musi, the standard DF ( $1 \%$ or more) occurred in the living room from 06.00 to 0.9 .00 a.m, and from 13.00 to 16.00 p.m (Fig. 3(d) and Tables 1). Daylight performance in the bedroom is much better where the standard DF $(0.5 \%$ or more $)$ was experienced throughout the day from 06.00 a.m. to 16.00 p.m (Table 2.). 
Table 2. Daylight factor in the bedroom

\begin{tabular}{|c|c|c|c|c|}
\hline \multirow{2}{*}{ Time } & \multicolumn{4}{|c|}{ DF in Colonial House (\%) } \\
\cline { 2 - 5 } & Siring & Nias & Sutomo & Musi \\
\hline 06 & 1.25 & 0.92 & 0.73 & 1.59 \\
\hline 07 & 0.43 & 0.42 & 0.90 & 1.25 \\
\hline 08 & 0.27 & 0.18 & 0.44 & 1.40 \\
\hline 09 & 0.19 & 0.11 & 0.41 & 2.61 \\
\hline 10 & 0.06 & 0.09 & 0.31 & 1.31 \\
\hline 11 & 0.03 & 0.07 & 0.43 & 0.81 \\
\hline 12 & 0.03 & 0.07 & 0.64 & 1.60 \\
\hline 13 & 0.05 & 0.06 & 0.67 & 1.96 \\
\hline 14 & 0.04 & 0.08 & 0.54 & 1.94 \\
\hline 15 & 0.05 & 0.18 & 0.84 & 2.23 \\
\hline 16 & 0.22 & 0.26 & 1.07 & 2.66 \\
\hline
\end{tabular}

The analysis shows that the colonial houses can have different daylight performances. These difference can be linked to design of the house which is obviously different from one to another, or it can be related to how occupant interact with the house.

Location of bedrooms and living rooms where the measurement was taken are all at the perimeter of the building. This means that all the room get greater opportunity to have natural light penetration. Since the number, size and position of windows are different from one house to another, illuminance received in the rooms will be different.

Houses HC3-Sutomo and HC4-Musi have a bigger size of windows as compared with the other houses (see elevation in Fig. 1. and Table 4.). Reception/living room in the four houses under study is commonly equipped with more windows than the bedroom. Aside from windows, living room in the HC3-Sutomo in particular also has two glass doors. Bedroom generally has only one window. The difference is in its size. Windows in the HC3-Sutomo and HC4-Musi are larger than those in the other houses, and made of glass. Windows of the bedroom in the HC1-Siring and HC2-Nias are made of timber in the form louvre. This type of window will reduce the number of light penetrating the building substantially especially when the window is closed.

Table 4. Materials of the building envelope

\begin{tabular}{|c|c|c|c|c|}
\hline \multirow{2}{*}{ Room } & \multicolumn{4}{|c|}{ Colonial House } \\
\cline { 2 - 5 } & Siring & Nias & Sutomo & Musi \\
\hline $\begin{array}{c}\text { door } \\
\text { (interior) }\end{array}$ & $\begin{array}{c}\text { wood } \\
\text { panel }\end{array}$ & $\begin{array}{c}\text { wood } \\
\text { panel }\end{array}$ & $\begin{array}{c}\text { wood } \\
\text { panel }\end{array}$ & $\begin{array}{c}\text { wood } \\
\text { panel }\end{array}$ \\
\hline $\begin{array}{c}\text { door } \\
\text { (eksterior) }\end{array}$ & none & none & none & $\begin{array}{c}\text { wood } \\
\text { panel }\end{array}$ \\
\hline window & $\begin{array}{c}\text { wood- } \\
\text { louvres }\end{array}$ & $\begin{array}{c}\text { wood- } \\
\text { louvres }\end{array}$ & glass & glass \\
\hline \multicolumn{5}{|c|}{ Living room } \\
\hline $\begin{array}{c}\text { door } \\
\text { (interior) }\end{array}$ & open & glass- & open & open \\
access & wood & access & access \\
\hline $\begin{array}{c}\text { door } \\
\text { (eksterior) }\end{array}$ & $\begin{array}{c}\text { glass- } \\
\text { wood }\end{array}$ & $\begin{array}{c}\text { glass- } \\
\text { wood }\end{array}$ & $\begin{array}{c}\text { glass } \\
(2 \text { pcs })\end{array}$ & $\begin{array}{c}\text { wood } \\
\text { panel }\end{array}$ \\
\hline window & glass & glass & glass & glass \\
\hline
\end{tabular}

Table 5. below illustrates utilisation schedule of doors and windows during the field measurements. It can be analysed for this table that both internal doors and windows in the bedroom of all houses were closed, with an exception in houses HC1-Siring and HC4-Musi. Windows in these house were open for certain purposes and time. The same tendency was also noted in the living/reception room. Since windows in the bedroom are not all made of glass, closing the windows, particularly those are in the form of wood louvre, will significantly reduce the daylight. However, the case is different in the living room where all of the windows are made of glass. Closing the window dos not give an influence on the light penetration as it never blocks the light.

Table 5. Utilitation schedule of doors and windows

\begin{tabular}{|c|c|c|c|c|}
\hline \multirow{2}{*}{ Room } & \multicolumn{4}{|c|}{ Colonial House } \\
\cline { 2 - 5 } & Siring & Nias & Sutomo & Musi \\
\hline \multicolumn{5}{|c|}{ Bedroom } \\
\hline $\begin{array}{c}\text { door } \\
\text { (interior) }\end{array}$ & close & close & close & close \\
\hline $\begin{array}{c}\text { door } \\
\text { (eksterior) }\end{array}$ & none & none & none & close \\
\hline window & $\begin{array}{c}\text { close } \\
\text { (when } \\
\text { sleeping) }\end{array}$ & close & close & $\begin{array}{c}\text { open } \\
(06.00- \\
17.00)\end{array}$ \\
\hline \multicolumn{5}{|c|}{ Living room } \\
\hline $\begin{array}{c}\text { door } \\
\text { (interior) }\end{array}$ & open & close & open & open \\
\hline $\begin{array}{c}\text { door } \\
\text { (eksterior) }\end{array}$ & close & close & close & close \\
\hline $\begin{array}{c}\text { open } \\
\text { window }\end{array}$ & $\begin{array}{c}(06.00- \\
17.00)\end{array}$ & close & close & $\begin{array}{c}\text { open } \\
(06.00- \\
17.00)\end{array}$ \\
\hline
\end{tabular}

In terms of building design and utilisation schedule, all of these characteristics explain why daylight performance in the HC3-Sutomo and HC4-Musi is better than HC1-Siring and HC2-Nias, and also why performance of the living room is better than the bedroom.

\subsubsection{Overall performance}

Comparing the overall performance of the building, it can be seen that good daylight performance in the living room can be found in HC3-Sutomo, HC2-Nias and HC4Musi (Fig. 4(a)). The lowest is recorded in HC2-Siring. In the HC3-Sutomo, the standard DF value (1\%) can be attained for about $81 \%$ of the 12-hour measurement (see Table 6. and Fig. 5.). In the HC2-Nias and HC3-Musi, the standard values were experienced for about 73 and $64 \%$ of the time respectively. House HC-1 Siring experienced the least, i.e. $36.4 \%$ of the time. The standard DF generally occurs during several hours in the morning and afternoon. 


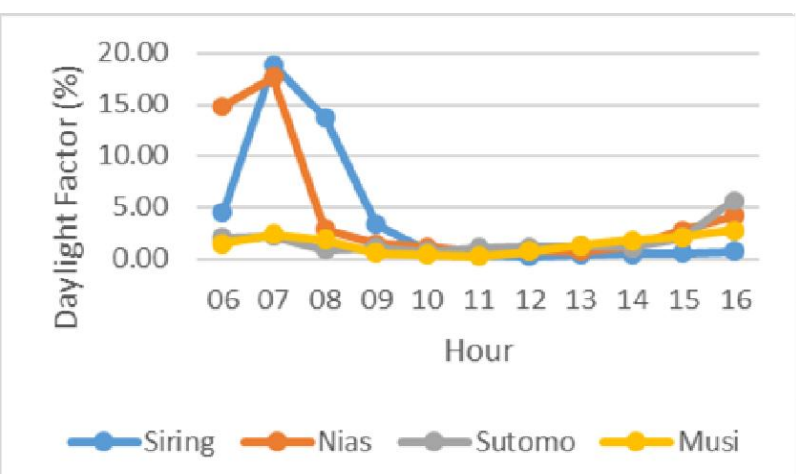

(a) Living room

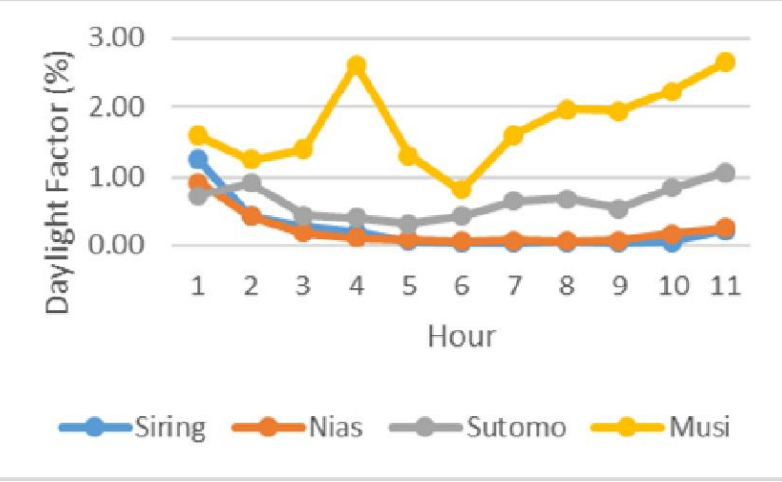

(b) Bedroom

Fig. 4. Daylight factor of the two main rooms under study

In the case of bedroom, Houses HC3-Sutomo and HC4-Musi experienced better daylight conditions as compared to houses HC1-Siring and HC2-Nias (see Fig. 4(b). and Table 6.). It can be seen from Table 6. that HC3-Sutomo experienced the standard DF for 7 hours or $63.6 \%$ of the time and HC4-Musi for 11 hours or $100 \%$ of the time (Fig. 5.). Houses HC1-Siring and HC2-Nias experienced sufficient daylight for only 1 hour or $9.1 \%$ of the time, and this occurred in the morning.

Table 6. Duration of sufficient daylighting

\begin{tabular}{|l|c|c|c|c|}
\hline \multirow{2}{*}{ Room } & \multicolumn{4}{|c|}{ Standard DF in Colonial House (hour) } \\
\cline { 2 - 5 } & Siring & Nias & Sutomo & Musi \\
\hline Bed-R & 1 & 1 & 7 & 11 \\
\hline Living-R & 4 & 8 & 9 & 7 \\
\hline
\end{tabular}

Overall the HC3-Sutomo and HC4-Musi have better daylight performance than the other two houses. Standard DF experienced in both living room and bedroom for most of the time. House HC2-Nias attained good standard DF in the living room, while the bedroom performed the worst. Similar pattern is shown in the $\mathrm{HC} 1$-Siring. In this case, DF in the living room is better than that in the bedroom.

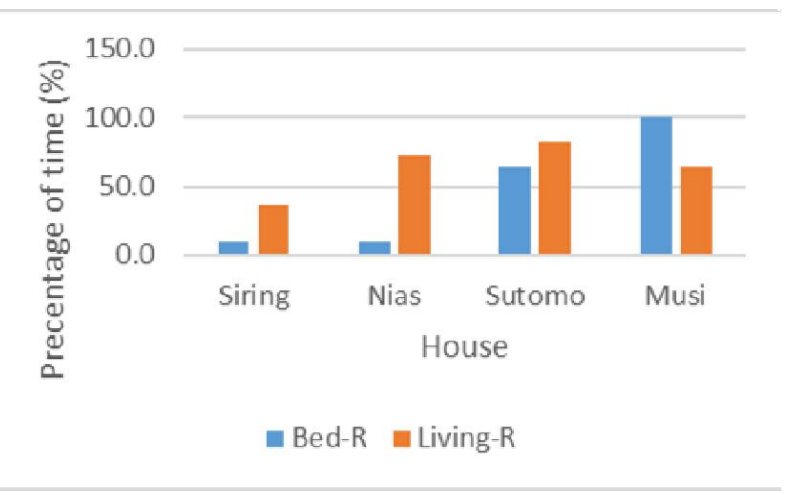

Fig. 5. Percentage of occurrence of sufficient daylighting

Daylight performance of the colonial house varies from one house to another. As mentioned before, the performance of the houses is greatly influenced by the schedule of opening doors and operable windows and design of the operable windows. As one may expect, when the windows and doors are open the daylight performance is better due to the high light penetration. In the case of HC3-Sutomo and HC4-Musi, the doors and windows were generally open in both living room and bedroom during the day, and thus contribute to the good performance of the houses. On the contrary, most of the doors and windows in the HC1-Siring and HC2-Nias were frequently closed during the day. This condition reduced the daylight, and consequently lower the performance of these two houses.

\subsection{Design potentials}

Daylight performance of a building is determined by design of the building such as layout, room's height and fenestration, and also affected by occupant's behaviour. The last mentioned factor will determine a schedule of opening doors and windows of the building. The above discussion underlines the influence of occupant's behaviour on the daylight performance of the house. The fact that design of the house poses good environmental potentials will not be noticeable if the occupant is not fully aware of its contribution.

As previously mentioned in section 1 , the colonial house has many environmental potentials. Layout of the house is generally arranged in such a way that internalexternal connection can be enhanced. Height of the building that may reach $4 \mathrm{~m}$, allows higher window's height. A combination of glass window and louvres in its fenestration system increases the daylight penetration while still keep the shading. The study has shown that these environmental design potentials have contributed to the good performance of the building.

\section{Conclusions}

From the above discussion, the study concludes that daylight performance of the colonial houses varies and not all of the buildings are able to provide better daylight in both bedroom and living room. Out of the four houses, houses HC3-Sutomo and HC4-Musi have the good performance which can be indicated by the longer time 
when the standard DF is experienced in the building. These two houses experienced the standard DF for at least 7 hours or more than $63 \%$ of the time. The HC2Nias attained good performance for the living room (more than $70 \%$ of time) but not for the bedroom (less than 10\%). The HC1-Siring were lack in light penetration in the both bedroom and living room (less than $70 \%$ of time).

The daylight performance is mainly endorsed by design of the house, i.e. layout, type and size of the window, but as the study shown the final performance is greatly affected by the occupant's behaviour. The good performance achieved by HC3-Sutomo and HC4-Musi is contributed by the design and utilisation schedule of door and window, which relates closely to the environmental awareness of the occupants. The performance of houses HC1-Siring and HC2-Nias tends to be influenced by the occupant's behaviour which in this case is not directly related to environmental aspects.

Given the utilisation schedule of door and window supporting the use of natural light, design of colonial house certainly reflects the tropical climate design principles, and therefore deserves further exploration and investigation regarding its response to natural light.

The authors wish to acknowledge the contribution of the Laboratory of Architectural Science \& Technology of ITS for allowing the study to use measurement equipment, and the support the Ministry of Research and Technology and Higher Education of the Republic of Indonesia for providing research grant under the scheme of Penelitian Unggulan Perguruan Tinggi (PUPT) ITS 2018.

\section{References}

1. P. Manurung, ITU AIZ, 14, 111 (2017)

2. V.A. Kumurur, D.M. Tampi, IOP Conference Series: Earth and Environmental Science, 129, 012030 (2018)

3. Rina W, Meyka W., JIDK, 2, 3 (2012)

4. Joko TS, Noviani S, Antariksa, JR, 11, 37 (2013)

5. Antonius A, Achmad D, Ikaputra, Jatmika AS, DIMENSI JABE, 41, 37 (2014)

6. Antonius A, Achmad D, Ikaputra, Jatmika AS, IJSRP, 5, 1 (2015)

7. I.G.N. Antaryama, S.N.N. Ekasiwi, A. Mappjaya, M.S. Ulum, IOP Conference Series : Earth and Environmental Science, 126, 012048 (2018)

8. P. Tregenza, M. Wilson, Daylighting, Architecture and Lighting Design (2011)

9. G.D. Ander, Daylighting, Performance and Design (1998)

10. A. Dinapradipta, E. Sudarma, I. Defiana, C. Erwindi, IOP Conference Series: Earth and Environmental Science, 126, 012046 (2018)

11. I.G.N. Antaryama, S.N.N. Ekasiwi, A. Mappjaya, Startegy of Climatic Control of Colonial Houses in Surabaya, Part I : Thermal Conditions (2017)
12. D. Heerwagen, Passive and Active Environmental Control: Informing the Schematic Designing of Buildings (2004) 